\title{
Diagnosis of water circulation in an estuary: A case study of the Jamapa River and the Mandinga lagoons, Veracruz, Mexico
}

\section{Diagnóstico de la circulación del agua en un estuario: Caso de estudio del río Jamapa y las lagunas de Mandinga, Veracruz, México}

\author{
Jose Antonio Gonzalez-Vazquez*, Erika Hernández-Vivar, Claudia Rojas-Serna, \\ Jair Del-Valle-Morales \\ Universidad Autónoma Metropolitana, Unidad Iztapalapa, Av. San Rafael Atlixco, no.186, Col. Vicentina, CP \\ 09340, Mexico City, Mexico.
}

* Corresponding author. E-mail: jgonzalezv@xanum.uam.mx

\begin{abstract}
The purpose of this study was to analyze water circulation in an estuary located in Boca del Río, Veracruz, Mexico. The diagnosis is based on the most representative flux records for the Jamapa River during the dry and rain seasons, that is, April and September, respectively. Tidal conditions, temperature, and water density were taken into account. For the diagnosis, a three-dimensional model (Delft3D) was applied. The seasonal circulation governing the estuary was evaluated using barotropic and baroclinic pressure levels. During the dry season, estuarine circulation was governed by the tides, and water circulation in the Mandinga lagoons was induced by baroclinic conditions. During the rainy season, the estuarine system was governed by discharge from the Jamapa River, and water circulation in the Mandinga lagoons is influenced by barotropic gradients.
\end{abstract}

Key words: estuary, Delft3D, barotropic, baroclinic, salinity.

RESUMEN. Este estudio analiza la circulación de agua en el estuario de Boca del Río, Veracruz, México. El diagnóstico se basa en los registros disponibles de los flujos del río Jamapa durante las estaciones de estiaje y lluvia, es decir, durante abril y septiembre, respectivamente. Los regímenes de mareas, la temperatura y los valores de densidad del agua fueron tomados en cuenta. Para el dignóstico, se aplicó un modelo en 3 dimensiones (Delft3D). La circulación estacional del agua en el estuario se evaluó de acuerdo con los niveles de presión barotrópica y presión baroclínica. Durante la temporada de estiaje, la circulación en el estuario se rigió por las mareas, mientras que la circulación en las lagunas de Mandinga es inducida por condiciones baroclínicas. Durante la temporada de lluvias, el estuario se rigió por la descarga del río Jamapa, y la circulación del agua en las lagunas de Mandinga dependió de los gradientes barotrópicos.

Palabras clave: estuario, Delft3D, barotrópico, baroclínico, salinidad.

\section{INTRODUCTION}

"An estuary is a semi-enclosed body of water with a free connection to the sea, where fresh water derived from land drainage measurably dilutes water from the ocean" (Pritchard 1967). Bathymetry, wind, temperature, relative humidity, solar radiation, precipitation, and the position of lagoons with respect to the direction of river discharge determine the circulation patterns, salinity intrusions, and temperature variations in an estuary. Estuarine ecosystems are important for the development of nearby settlements, recreational activities, expansion of scientific knowledge, and the survival of endemic species and other species that spend part of their life cycle in these systems. These ecosystems produce high amounts of land-sea nutrients, and vegetation and system dynamics in them act as a natural buffer between the sea and land.

For the diagnosis of estuarine circulation, we need to take into account the dynamic behavior of an estuary under the ordinary dry and rainy seasons and how this behavior

\section{INTRODUCCIÓN}

"Un estuario es un cuerpo de agua costero semicerrado que tiene una conexión libre con el mar y en el cual el agua de mar se diluye de manera mensurable con agua dulce derivada de una descarga de la tierra” (Pritchard 1967). La batimetría, el viento, la orientación de las lagunas con respecto a la dirección de descarga del río, la temperatura, la humedad relativa, la radiación solar y la precipitación pluvial determinan los patrones de la circulación, la intrusión salina y la variación de la temperatura en un estuario. Los sistemas estuarinos son esenciales para el desarrollo de las poblaciones aledañas, la recreación, el conocimiento científico y la supervivencia de especies endémicas y otras que pasan ahí parte de su ciclo de vida. En estos sistemas la productividad de nutrientes entre la tierra y el mar es alta, y la vegetación y la dinámica del sistema actúan como un amortiguador natural entre la tierra y el mar.

Para obtener un diagnóstico de la circulación del agua en un estuario, es indispensable conocer el comportamiento 
relates to the most significant forcing agents (tide, river discharge, wind, temperature, salinity, and bathymetry of the estuary). Shallow estuarine lagoons present zones where velocity magnitudes are very low, and water circulation in the system will therefore be influenced mainly by pressure gradients, bottom shear stress (friction), surface wind stress, and, for lagoons that are wider than the Rossby radius of deformation, the Coriolis effect (Gill and Rasmusson 1983). An analysis of the momentum equation, which requires an analysis of barotropic pressure caused by variations in sea level and an analysis of baroclinic pressure, is performed to study water movements in the system. Some results have demonstrated that substantial gravitational circulation can develop in shallow, weakly stratified estuarine lagoons (Jian and Li 2012).

The diagnosis of estuarine circulation consists in analyzing field measurements including salinity, tidal phases, flux velocity, transport (flux per unit area), and bathymetries (Carlin et al. 2016, Xu et al. 2017). To completely characterize an estuary, numerical models allow obtaining current circulation patterns must be applied (Panda et al. 2013, Gonzalez-Vazquez et al. 2018). Both studies are complementary in the diagnosis of estuarine circulation because, even though circulation can be inferred from well-designed field experiments, at present it is not possible to monitor all temporal variabilities of currents all around the system. On the other hand, while numerical models allows us to obtain the temporal and spatial variabilities of currents throughout the system domain, the information provided by field surveys is important for the calibration and validation of the circulation patterns obtained with numeric models.

Many numerical circulation models can be applied for estuaries (Salas-Monreal et al. 2018), with some sing tracers or pressure gradients in the system (Mahanty et al. 2016). More recently, three-dimensional (3D) models have been used to determine hydrodynamic behavior with free-surface, velocity, and salinity conditions associated with the dry and rainy seasons in the site (Zhu et al. 2015, Barrios-Piña et al. 2016).

Mean circulation and stratification are fundamental factors in the transport of nutrients, contaminants, and fish larvae in estuarine systems (Paerl et al. 1998, Werner et al. 1999, Vargas et al. 2017). The Venice System Scheme (The Venice System... 1958) is used to regionalize an estuary according to salinity levels; this scheme sections the estuary into 5 region types that provide an ecological characterization of the system according to the following salinity scales: limnetic (freshwater region, $<0.5$ ), oligohaline ( 0.5 to 5.0 ), mesohaline ( 5 to 18 ), polyhaline (middle region, 18 to 25; lower region, 25 to 30), and euhaline (30 to 35).

Estuaries can be considered shallow bodies of water that are associated with tidal phases, wave forces, and flux velocities; therefore, equations for shallow waters can be dinámico del sistema estuarino en condiciones climatológicas ordinarias de estiaje y de lluvias, y en función de sus forzantes más significativas, como la marea, el flujo del río, el viento, la temperatura, la salinidad y la batimetría del estuario. En el caso de lagunas estuarinas someras, las magnitudes de la velocidad de la circulación del agua pueden ser muy bajas en algunas zonas, por lo que la circulación del sistema estará mayormente ligada a las variaciones de la presión, los esfuerzos cortantes en el fondo (fricción) y en la superficie (esfuerzo del viento), y, para lagunas más anchas que el radio de deformación de Rossby, el efecto de Coriolis (Gill y Rasmusson 1983). Para estudiar el movimiento del agua se realiza un análisis de la ecuación de momento, que implica un análisis de presión barotrópica ocasionada por la variación del mar y un análisis de presión baroclínica. Algunos resultados demostraron que la circulación gravitacional sustancial puede desarrollarse en estuarios lagunares poco profundos y débilmente estratificados (Jian y Li 2012).

Parte del diagnóstico de la circulación de un estuario consiste en analizar datos obtenidos de mediciones en campo para registrar condiciones de salinidad, marea, velocidades de flujo, transporte (flujo por unidad de área) y batimetrías (Carlin et al. 2016, Xu et al. 2017). Para caracterizar un estuario por completo, es necesario aplicar modelos numéricos que permitan conocer los patrones de circulación de las corrientes (Panda et al. 2013, Gonzalez-Vazquez et al. 2018). Ambos trabajos son complementarios en un estudio de circulación de un estuario, pues si bien la circulación puede ser inferida con base en experimentos de campo bien diseñados, no es posible en la actualidad monitorear toda la variabilidad temporal de las corrientes en cada punto del sistema. Por otro lado, aunque la aplicación de modelos numéricos nos permite conocer la variabilidad temporal y espacial de las corrientes en todo él domino del sistema, la información que nos proveen las campañas de medición son importantes para calibrar y validar los patrones de circulación obtenidos con los modelos numéricos.

Existe una gran diversidad de modelos numéricos de circulación aplicables a estuarios (Salas-Monreal et al. 2018), algunos mediante trazadores o variaciones de presión en el sistema (Mahanty et al. 2016). Últimamente se han empleado modelos en 3 dimensiones (3D) para determinar el comportamiento hidrodinámico con la variación de la superficie libre, la velocidad y la salinidad en condiciones de lluvia y estiaje (Zhu et al. 2015, Barrios-Piña et al. 2016).

La circulación media y su estratificación en capas es un factor fundamental para el transporte de nutrientes, contaminantes y larvas de peces en sistemas estuarinos (Paerl et al. 1998, Werner et al. 1999, Vargas et al. 2017). Para regionalizar las zonas de un estuario en función de la salinidad, se emplea el Venice System Scheme (The Venice system... 1958), que consiste en seccionar el estuario en 5 zonas que proveen una caracterización ecológica sobre el sistema, con la escala de salinidad: limnético (región de agua dulce, $<0.5$ ), oligohalino (0.5 a 5.0), mesohalino (5 a 
adequate to study estuaries. However, a variating condition of vertical density as a product of saline waters from the sea and fresh water from river discharges is necessary for circulation analyses. This condition is essential for the hydrodynamic circulation and salinity in the system. Therefore, the study must consider the vertical variation of salinity to establish saline intrusion conditions along the profiles of the river and the lagoon system, and changes in density and temperature (Lesser et al. 2004).

This study analyzes a 3D hydrodynamic model (Delft3D, Roelvink and van Banning 1995) to estimate water circulation conditions in the Boca del Río Estuary (Veracruz, Mexico), taking into account that, even in the shallow waters of the Mandinga Chica Lagoon and Mandinga Grande Lagoon, the circulation will be influenced by baroclinic and barotropic pressure gradients. Though in the field data the system shows a uniform salinity condition throughout most of the system and a dominance of shallow conditions, the implementation of a 3D model is fundamental due to interactions with the open sea at the mouth of the system and density variations, which influence barotropic and baroclinic pressure in the estuary.

\section{MATERIALS AND METHODS}

\section{Study area}

The system is formed by the Jamapa River, the estuary, the Mandinga Chica Lagoon, and the Mandinga Grande Lagoon. The system is located between $18^{\circ} 58^{\prime} \mathrm{N}$ and $19^{\circ} 06^{\prime} \mathrm{N}$ and $96^{\circ} 01^{\prime} \mathrm{W}$ and $96^{\circ} 08^{\prime} \mathrm{W}$, in Boca del Río, Veracruz, Mexico (Fig. 1).

The estuary extends over an area of $2.13 \mathrm{~km}^{2}$ with an island formed at the mouth of the Mandinga Chica Lagoon; the island has an area of $0.27 \mathrm{~km}^{2}$. The estuary is a 9.18-km long meandering channel with an average depth of $3 \mathrm{~m}$. The Mandinga Chica Lagoon has an area of $1.72 \mathrm{~km}^{2}$ and a perimeter of $5.13 \mathrm{~km}$; the lagoon entrance has a maximum depth of $22 \mathrm{~m}$, whereas the inner lagoon has a maximum depth of $0.9 \mathrm{~m}$. A 2-km long channel with depths of 2.08-3.27 m connects Mandinga Chica Lagoon with Mandinga Grande Lagoon. The Mandinga Grande Lagoon has an area of $16.24 \mathrm{~km}^{2}$, a perimeter of $17.13 \mathrm{~km}$, and an average depth of $0.8 \mathrm{~m}$. The water flux in the lagoon system depends solely on the discharge of the Jamapa River and the connection with the open sea; there is no relevant surface runoff in the area. The Jamapa River is the main channel of the system. During the dry season, average flux is $14.2 \mathrm{~m}^{3} \cdot \mathrm{s}^{-1}$; during the rainy season, average flux is $135.7 \mathrm{~m}^{3} \cdot \mathrm{s}^{-1}$. The average flux reached values higher than $1,000 \mathrm{~m}^{3} \cdot \mathrm{s}^{-1}$ due to extreme weather conditions during Hurricane Karl in 2010 (CONAGUA 2012, Riveron-Enzastiga et al. 2016, González-Vázquez et al. 2018).
18), polihalino (región media, 18 a 25; región baja, 25 a 30) y euhalino (30 a 35).

Los estuarios pueden ser considerados cuerpos de agua someros con relación a la profundidad necesaria para la propagación de ondas de marea, a las fuerzas generadas por el oleaje y a las velocidades del flujo. Entonces, la aplicación de las ecuaciones para aguas someras puede ser adecuada para su estudio. Sin embargo, en el análisis de la circulación es necesaria una condición de variación de la densidad en la vertical, como producto de la salinidad proveniente del agua de mar y de la descarga de agua dulce del río. Está condición será esencial para la circulación hidrodinámica y la salinidad dentro del sistema. El estudio entonces deberá considerar una variación de la salinidad en la vertical, donde se puedan establecer las condiciones de la intrusión salina a lo largo del perfil del río y del sistema lagunar, así como los cambios de densidad y de temperatura (Lesser et al. 2004).

En este estudio se realiza un análisis por medio de un modelo hidrodinámico en 3D (Delft3D, Roelvink y van Banning 1995) para estimar las condiciones de la circulación de agua en el estuario de Boca del Río, Veracruz, México, considerando que aún en aguas poco profundas como la laguna Chica de Mandinga y la laguna Grande de Mandinga, el comportamiento del estuario estará influenciado por los gradientes de presión baroclínica y barotrópica. Si bien el sistema muestra, según los registros de campo, una condición de salinidad uniforme en la mayor parte y que se rige por las condiciones de poca profundidad, la implementación de un modelo 3D es fundamental debido a la interacción de la boca del sistema con el mar y a la variación de densidad. Lo anterior repercutirá en la presión barotrópica y baroclínica en el estuario.

\section{MATERIALES Y MÉTODOS}

\section{Área de estudio}

El sistema está formado por el río Jamapa, el estero, la laguna Chica de Mandinga y la laguna Grande de Mandinga. El sistema se localiza entre las coordenadas $18^{\circ} 58^{\prime}$ y $19^{\circ} 06^{\prime} \mathrm{N}$ y $96^{\circ} 01^{\prime}$ y $96^{\circ} 08^{\prime} \mathrm{W}$, en Boca del Río, estado de Veracruz, México (Fig. 1).

El estero de la laguna tiene un área de $2.13 \mathrm{~km}^{2}$ y una isla formada justo en la boca de la laguna Chica de Mandinga; la isla tiene un área de $0.27 \mathrm{~km}^{2}$. El estero es un canal de meandros que mide $9.18 \mathrm{~km}$ de largo, $3 \mathrm{~m}$ de profundidad promedio. La laguna Chica de Mandinga mide $1.72 \mathrm{~km}$ de longitud y tiene un perímetro de $5.13 \mathrm{~km}$; en la entrada de la laguna la profundidad máxima es de $2.2 \mathrm{~m}$, y en su interior la profundidad máxima es de $0.9 \mathrm{~m}$. El canal que conecta a la laguna Chica y a la laguna Grande tiene $2 \mathrm{~km}$ de longitud y entre 2.08 y $3.27 \mathrm{~m}$ de profundidad. La laguna Grande de Mandinga tiene un área 16.24 km², un perímetro de $17.13 \mathrm{~km}$ y una profundidad promedio de $0.8 \mathrm{~m}$. El flujo en el sistema lagunar depende únicamente de la aportación del río Jamapa 


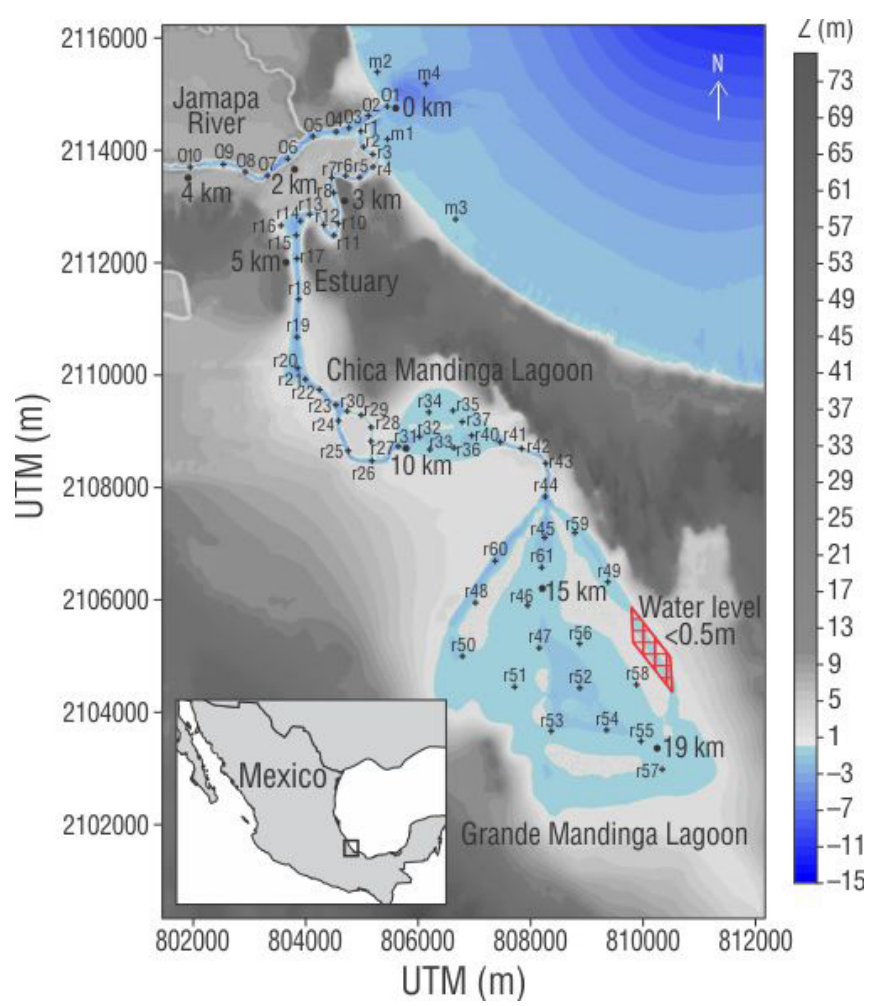

Figure 1. Study area and control stations $(+)$. Circles indicate the length of the system from the breakwaters. The red square indicates water level under $0.5 \mathrm{~m}$.

Figura 1. Zona de estudio y estaciones de control (+). Los círculos indican la longitud del sistema a partir de las escolleras, y el cuadro rojo indica nivel de agua menor que $0.5 \mathrm{~m}$.

\section{Analysis}

The study area was integrated by the bathymetry obtained in the field with an echosounder and the topography plug-in of the Mexican Elevation Continuum (CEM, for its acronym in Spanish) in UTM (Fig. 1). The river within the study area has a length of $5 \mathrm{~km}$ upstream from the river mouth. The analysis of the estuary in the numerical model considers the forcing agents, a regular grid, and a 3D system with 5 levels determined by depth every 20\%, E1 at the free surface and E5 at the bottom. The forcing agents considered were the tide, the Jamapa River discharge, temperature, and density.

The tide is the forcing agent on the seaside. This is formed by components $\mathrm{M}_{2}, \mathrm{~N}_{2}, \mathrm{~K}_{1}, \mathrm{~K}_{2}, \mathrm{P}_{1}, \mathrm{O}_{1}$, and $\mathrm{S}_{2}$ with amplitude values in meters of $\mathrm{M}_{2}=0.089, \mathrm{~N}_{2}=0.023, \mathrm{~K}_{1}=0.156, \mathrm{~K}_{2}=$ $0.006, \mathrm{P}_{1}=0.049, \mathrm{O}_{1}=0.153$, and $\mathrm{S}_{2}=0.026$ and phases in grades of $\mathrm{M}_{2}=71.17, \mathrm{~N}_{2}=59.41, \mathrm{~K}_{1}=289.36, \mathrm{~K}_{2}=55.76$, $\mathrm{P}_{1}=290.99, \mathrm{O}_{1}=289.84$, and $\mathrm{S}_{2}=68.58$ (SEMAR 2010, Salas-Monreal et al. 2019). $\mathrm{K}_{1}, \mathrm{O}_{1}$, and $\mathrm{M}_{2}$ show the highest amplitudes; therefore, the tide can be considered to be diurnal with average high water of $0.478 \mathrm{~m}$ and average low water of $0.133 \mathrm{~m}$ using as reference the tidal datum of the Mean Lower Low Water (MLLW) and $0.0 \mathrm{~m}$ elevation. y de la conexión con el mar. No existe un escurrimiento importante en la zona. El río Jamapa es el cauce principal del sistema. En época de estiaje el flujo medio del río es de $14.2 \mathrm{~m}^{3} \cdot \mathrm{s}^{-1} \mathrm{y}$ en época de lluvias es de $135.7 \mathrm{~m}^{3} \cdot \mathrm{s}^{-1}$, pero ha alcanzado valores mayores que $1,000 \mathrm{~m}^{3} \cdot \mathrm{s}^{-1}$ debido a fenómenos extremos como el huracán Karl en 2010 (CONAGUA 2012, Riveron-Enzastiga et al. 2016).

\section{Análisis}

El área de estudio fue integrada por la batimetría registrada en campo mediante una ecosonda y por el complemento de la topografía obtenida del Continuo de Elevaciones Mexicano (CEM) en UTM (Fig. 1). El río en el dominio tiene una longitud aproximada de $5 \mathrm{~km}$ aguas arriba, a partir de la desembocadura al mar. El análisis del estuario en la modelación numérica considera los forzantes del sistema, sobre una malla regular y un sistema en 3D de 5 niveles a cada 20\% con relación a la profundidad, E1 en superficie libre y E5 en el fondo. Los forzantes considerados para integrar el sistema fueron marea, flujo del río Jamapa, temperatura y densidad.

La marea como forzante del lado mar está formada por las componentes $\mathrm{M}_{2}, \mathrm{~N}_{2}, \mathrm{~K}_{1}, \mathrm{~K}_{2}, \mathrm{P}_{1}, \mathrm{O}_{1}$ y $\mathrm{S}_{2}$, con valores de amplitud en metros de $\mathrm{M}_{2}=0.089, \mathrm{~N}_{2}=0.023, \mathrm{~K}_{1}=0.156, \mathrm{~K}_{2}=$ 0.006, $\mathrm{P}_{1}=0.049, \mathrm{O}_{1}=0.153 \mathrm{y} \mathrm{S}_{2}=0.026$ y fases en grados de $\mathrm{M}_{2}=71.17, \mathrm{~N}_{2}=59.41, \mathrm{~K}_{1}=289.36, \mathrm{~K}_{2}=55.76, \mathrm{P}_{1}=290.99$, $\mathrm{O}_{1}=289.84$ y S$_{2}=68.58$ (SEMAR 2010, Salas-Monreal et al. 2019). Las mayores amplitudes se presentan en $K_{1}, O_{1} y$ $\mathrm{M}_{2}$; entonces, la marea puede considerarse como diurna con un nivel de pleamar media de $0.478 \mathrm{~m}$ y un nivel de bajamar media de $0.133 \mathrm{~m}$ con nivel de referencia al nivel de bajamar media inferior y elevación de $0.0 \mathrm{~m}$.

Para el río Jamapa, como segundo forzante del sistema, se analizó el registro de las estaciones hidrométricas (CONAGUA 2012). A partir de los registros diarios, se determinaron los promedios mensuales y las condiciones ordinarias más representativas. El flujo promedio mensual en la condición de estiaje (abril) fue de $14.2 \mathrm{~m}^{3} \cdot \mathrm{s}^{-1} \mathrm{y}$ en la condición de lluvias (septiembre) fue de $135 \mathrm{~m}^{3} \cdot \mathrm{s}^{-1}$. Para la aplicación del forzante al sistema, de los valores promedio y del registro histórico (1951-2014), se determinó un año representativo, que sería el año con la menor desviación estándar; el año 2006 fue el más adecuado, y se modelaron, entonces, los meses de abril y septiembre de 2006 (Fig. 2 a, b).

En periodos de meses y estaciones del año, las variaciones de la temperatura y los gradientes de densidad que estas inducen dependen prioritariamente de la temperatura del agua del océano adyacente, que es trasmitida por la convección forzada del intercambio de volúmenes de agua salada entre el mar y la laguna producido por la marea, por las fluctuaciones estacionales de la radiación solar y por las fluctuaciones estacionales de la convección forzada por las descargas de agua dulce del río (Farreras 2006). En abril el agua del sistema lagunar registró una temperatura aproximada de $28{ }^{\circ} \mathrm{C}$ y una salinidad de 30 , mientras que en septiembre la temperatura 
For the Jamapa River discharge, the second forcing agent, records of hydrometric stations were analyzed (CONAGUA 2012). Daily records were used to determine monthly averages and the most representative ordinary conditions. Average flux values were $14.2 \mathrm{~m}^{3} \cdot \mathrm{s}^{-1}$ in the dry season (April); whereas, average flux values were $135 \mathrm{~m}^{3} \cdot \mathrm{s}^{-1}$ in the rainy season (September). A typical year had to be determined to apply the forcing agent to the system. Average values and historical records (1951-2014) were used to determine a typical year as the year with the least standard deviation. The year 2006 was the most adequate and April and September 2006 were modeled (Fig. 2a, b).

Variations in the temperature and the salinity gradients these induce are observed in periods of months and seasons and depend on the water temperature of the adjacent sea. This is transmitted through convection forced by the exchange of saline water volumes between the sea and lagoon, due to the tide; by seasonal fluctuations of solar radiation; and by seasonal fluctuations of convection forced by freshwater discharged by the river (Farreras 2006). In April, the approximate temperature and salinity in the water of the lagoon system were $28{ }^{\circ} \mathrm{C}$ and 30 , respectively; whereas, in September the temperature and salinity were $31{ }^{\circ} \mathrm{C}$ and 8 , respectively. The records were obtained from the entrance of the Mandinga Grande Lagoon.

The DELFT3D model was applied to all historical records and some data collected in the field such as bathymetry and temperature variations in the lagoon, river, and sea. Roughness parameters were obtained from Chow (1959). Physical parameters were obtained from the reference manual Hydraulics Deltares (2006).

\section{RESULTS}

The analysis of the results of the numerical model refers to April as the dry season and September as the rainy season. Variations on the free surface were analyzed according to the control stations O1, O9, r43, and r57 (Fig. 1). Station O1, located at the river mouth to the open sea, presented very similar water variations during dry and rainy seasons, with maximum and minimum values between 0.20 and $-0.15 \mathrm{~m}$, respectively (Fig. 2c). Station O9, located $\sim 4 \mathrm{~km}$ upstream from the mouth on the Jamapa River, showed a variation of the free surface from $0.20 \mathrm{~m}$ to $-0.05 \mathrm{~m}$ during the dry season, caused by the tide. During the rainy season, the variation of the free surface was dominated by river discharge not the tide and behaved similarly to the hydrogram of September with minimum and maximum values of $0.4 \mathrm{~m}$ and $1.8 \mathrm{~m}$, respectively (Fig. 2d). Stations r43 and r57 (Fig. 2e, f), located at the entrance and end of the Mandinga Grande Lagoon, respectively, showed that the variation of the free surface behaved similarly to the tide. Flux variations caused a superelevation of $2 \mathrm{~cm}$ during April and $10 \mathrm{~cm}$ during September in the Mandinga Grande Lagoon. The lagoon behaved similarly to the River Jamapa discharge when river discharge increased fue de $31^{\circ} \mathrm{C}$ y la salinidad de 8 . Los registros fueron realizados en la entrada de la laguna Grande de Mandinga.

El modelo Delft3D fue aplicado utilizando todos los registros históricos y algunos datos recabados en campo, como la batimetría y las variaciones de temperatura en la laguna, el río y el mar. Los parámetros de rugosidad se obtuvieron de Chow (1959). Los parámetros físicos fueron tomados del manual de referencia Hydraulics Deltares (2006).

\section{Resultados}

El análisis de los resultados de la modelación numérica está referido para el mes de abril como condición de estiaje y para el mes de septiembre como condición de lluvias. La variación en la superficie libre se analizó de acuerdo con los puntos de control: O1, O9, r43, r57 (Fig. 1). Durante la temporada de estiaje y la de lluvias, punto O1, ubicado en la desembocadura del río al mar, presenta un comportamiento muy similar en las variaciones del nivel de agua, con valores máximos y mínimos de 0.2 y $-0.15 \mathrm{~m}$, respectivamente (Fig. 2c). Para el punto O9, ubicado aproximadamente a $4 \mathrm{~km}$ aguas arriba de la desembocadura, sobre el río Jamapa, en el periodo de estiaje la superficie libre varió de 0.20 a $-0.050 \mathrm{~m}$, afectada por las condiciones de marea. Para la temporada de lluvias, la marea no influyó en la variación de la superficie libre; fue el flujo del río el que dominó el sistema con un comportamiento similar al hidrograma de septiembre, con valores mínimos de 0.4 m y máximos de $1.8 \mathrm{~m}$ (Fig. 2d). En las condiciones de variación de la superficie libre al interior de la laguna Grande de Mandinga, los puntos r43 y r57 (Fig. 2e, f), ubicados en la entrada y al final de la laguna, respectivamente, indicaron un comportamiento similar al obervado para la marea. La variación del flujo causó una sobreelevación de $2 \mathrm{~cm}$ en abril y de hasta $10 \mathrm{~cm}$ en septiembre en la laguna Grande de Mandinga. Cuando se presentó un incremento de flujo en septiembre, la laguna presentó un comportamiento similar al observado para la descarga del río Jamapa, con un retraso entre la entrada del flujo al sistema y la laguna Grande de Mandinga de aproximadamente $36 \mathrm{~h}$.

Para los resultados de la velocidad, se generaron 2 secciones a lo largo del estuario, una en el río y otro en la laguna. Para el río Jamapa, en las condiciones de estiaje, las velocidades variaron de 0 a $0.2 \mathrm{~m} \cdot \mathrm{s}^{-1}$. De la desembocadura y hasta $1.5 \mathrm{~km}$ aguas arriba, el río presentó una variación importante tanto en la magnitud como en la dirección de velocidad, producto de la marea (pleamar o bajamar). El río es dominado por el ingreso del flujo de agua de mar, con velocidades en la parte inferior de $0.1 \mathrm{~m} \cdot \mathrm{s}^{-1}$ en dirección de ingreso al estuario, mientras que en la parte de la superficie presentó una magnitud de $0.2 \mathrm{~m} \cdot \mathrm{s}^{-1}$ en dirección de la descarga hacia el mar, con un estado que tendió a velocidad cero en la parte media del perfil, lo cual refleja una tipíca circulación estuarina. Esta característica establece el dominio de la marea sobre el río en condiciones de estiaje para los primeros $1.5 \mathrm{~km}$. Para el tramo mayor que 

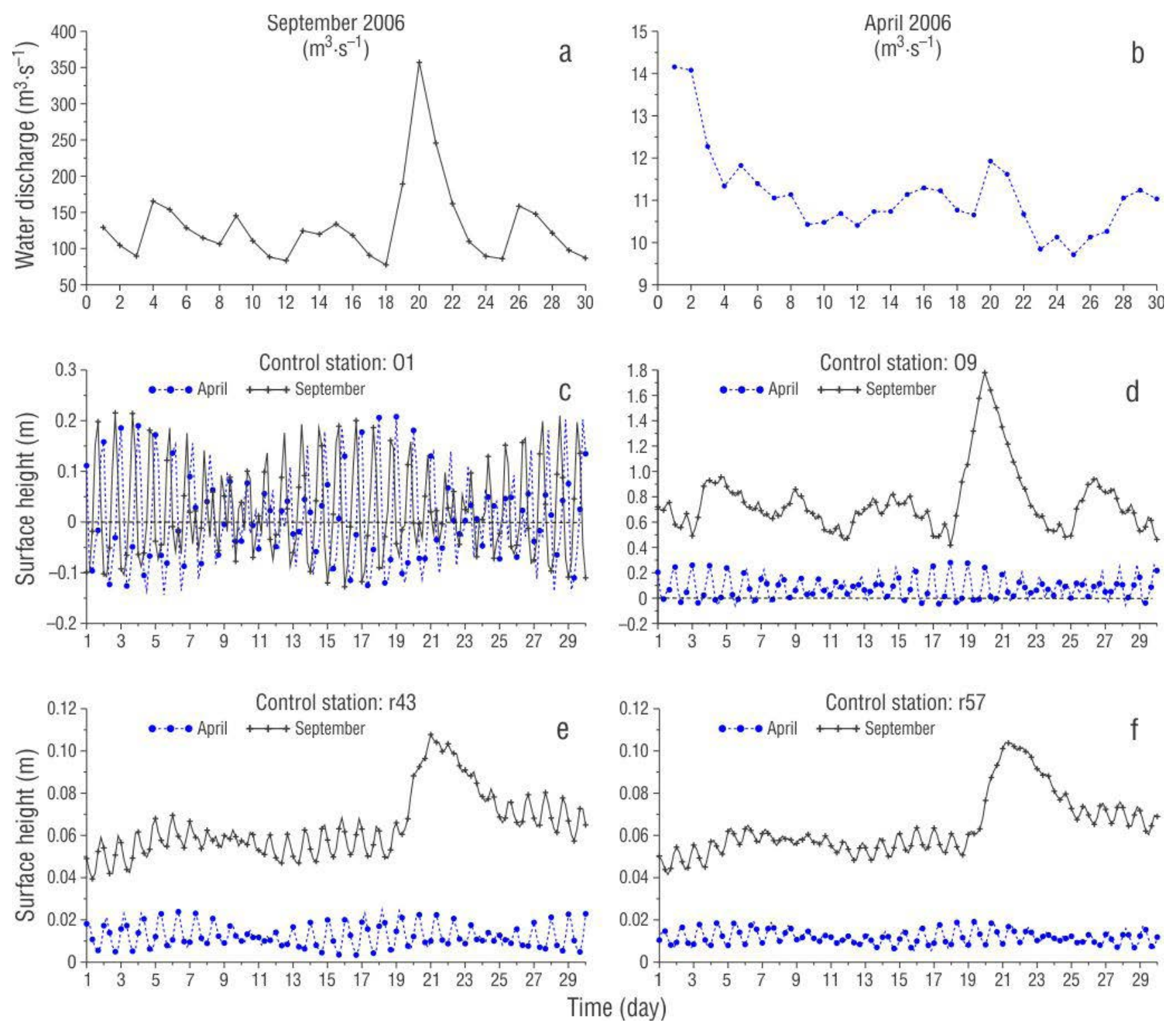

Figure 2. Daily average flux for the Jamapa River during the (a) rainy season and (b) dry season. Height of the water surface at stations (c) O1, (d) O9, (e) r43, and (f) r57, for each season.

Figura 2. Flujo promedio diario del río Jamapa en (a) temporada de lluvias y (b) temporada de estiaje. Se muestra la altura de la superficie del agua en las estaciones (c) O1, (d) O9, (e) r43 y (f) r57 en cada temporada.

during September. The system showed a 36-h delay between the flux entrance to the system and the flux entrance to the Mandinga Grande Lagoon.

Two sections along the estuary were used to analyze velocity: one in the river and one in the lagoon. In dry conditions, the Jamapa River showed velocities from 0.0 to $0.2 \mathrm{~m} \cdot \mathrm{s}^{-1}$. The river showed important velocity variations in magnitude and direction from the mouth of the system to $1.5 \mathrm{~km}$ upstream caused by the tide (high water and low water); variations were dominated by the inflow of sea waters with a magnitude of $0.1 \mathrm{~m} \cdot \mathrm{s}^{-1}$ at the bottom with an estuary-ward direction, a magnitude of $0.2 \mathrm{~m} \cdot \mathrm{s}^{-1}$ with a seaward discharge direction at the surface, and a magnitude that tended to zero
$1.5 \mathrm{~km}$, aguas arriba del río, el flujo presentó una magnitud de $0.1 \mathrm{~m} \cdot \mathrm{s}^{-1}$ y una dirección de descarga del sistema hacia el mar, condición uniforme en toda la vertical y en ambos estados de marea (Fig. 3a, c).

En septiembre, el río mostró un comportamiento más regular en todo su dominio, desde su desembocadura hasta los $3.5 \mathrm{~km}$ aguas arriba, con un valor de velocidad aproximado de $0.8 \mathrm{~m} \cdot \mathrm{s}^{-1}$ en dirección del mar. Para esta condición, no se presentó un ingreso de agua proveniente del mar para ninguna fase de marea, lo cual indica una nula intrusión salina al río durante la época de lluvias (Fig. 3b, e). Para la segunda sección del estuario, ubicada en el sistema lagunar, con longitud aproximada de $19 \mathrm{~km}$ desde la entrada al estero hasta la laguna 
in the middle of the profile, which showed a typical estuarine circulation. Therefore, the tide dominated the river in the first $1.5 \mathrm{~km}$ during the dry season. Further upstream, the flux showed a magnitude of $0.10 \mathrm{~m} \cdot \mathrm{s}^{-1}$ with a seaward discharge direction; this condition was uniform throughout depth levels and for both types of tide (Fig. 3a, c).

In September, the river showed a more consistent behavior throughout its domain, from the mouth to $3.5 \mathrm{~km}$ upstream, with a velocity of $0.8 \mathrm{~m} \cdot \mathrm{s}^{-1}$ and a seaward direction. For this season there was no inflow of seawater during either type of tide, which indicated that there were no saline water intrusions to the river during the rainy season (Fig. 3b, e). The second section, which was located in the lagoon system and measured $\sim 19 \mathrm{~km}$ in length from the estuary entrance to the Mandinga Grande Lagoon, showed, in dry conditions, an irregular behavior up to $4 \mathrm{~km}$ upstream from the estuary entrance, with maximum velocities of $0.06 \mathrm{~m} \cdot \mathrm{s}^{-1}$ with a uniform direction at all depth. From $4 \mathrm{~km}$ onward, velocities showed a regular flux throughout all depth levels, but varied in direction; the system is more regular up to the Mandinga Grande Lagoon, where depth levels showed inverted directions with near to zero velocities (Fig. 3e, g). During the rainy season, the Mandinga lagoons showed lower velocities than during the dry season, barely reaching $0.03 \mathrm{~m} \cdot \mathrm{s}^{-1}$, in spite of the non-uniform fluxes observed on all depths levels in the first $4 \mathrm{~km}$ of the section. Velocity increased because the cross-section between the lagoons decreased; then, the velocity decreased because the cross-sectional area of each lagoon increased. From the entrance of the Mandinga Grande Lagoon, at kilometer 13, the velocity decreased to near zero (Fig. 3f, h).

Flux increased between 18 and 24 September and caused a superelevation of $10 \mathrm{~cm}$ in the Mandinga Grande Lagoon; however, the variation of the velocity was minimum, whereas in the zone of breakwaters (station O1, Fig. 1) velocity values reached $0.8 \mathrm{~m} \cdot \mathrm{s}^{-1}$ (Fig. 4a-d). The relation Qsea/Qriver was used to determine the dominant effect in the estuary between the river discharge and the inflow from the sea; cross-sections were used to evaluate the fluxes in the sections. The relation Qsea/Qriver showed that the river discharge dominated the system in September, whereas the tide dominated the system in April.

A bidimensional analysis of velocities showed that in dry conditions maximum velocities in the system were $0.10 \mathrm{~m} \cdot \mathrm{s}^{-1}$ at the surface with a seaward direction and $0.05 \mathrm{~m} \cdot \mathrm{s}^{-1}$ at the bottom with an inward direction; this behavior persisted for every phase of the tide. Velocity magnitudes were greater between the entrance to the lagoon and the discharge to the sea, and decreased toward the inner estuary and upstream (Fig. 5a-d). The system showed a uniform behavior at all depth levels with a constant seaward discharge during rainy conditions. Even during high water and with flux toward the inner estuary, the Jamapa River discharge inhibited the entrance of the tide and the river flux dominated circulation in the lagoon system (Fig. 5e-h).
Grande de Mandinga. El sistema en condiciones de estiaje mostró un comportamiento irregular hasta $4 \mathrm{~km}$ a partir de la entrada al estero, con velocidades máximas de $0.06 \mathrm{~m} \cdot \mathrm{s}^{-1}$ y dirección uniforme en la profundidad. Las velocidades a partir del kilómetro cuatro presentaron un flujo regular en la vertical, pero, en direcciones variables según la profundidad, el sistema fue más regular hasta llegar a la laguna Grande de Mandinga, donde las capas presentaron direcciones invertidas y velocidades casi nulas. (Fig. 3e, g). En condiciones de lluvias las lagunas de Mandinga presentan velocidades más bajas que en condiciones de estiaje; si bien existe un flujo no uniforme sobre la vertical en los primeros $4 \mathrm{~km}$ de la sección, la velocidad apenas alcanzó valores de $0.03 \mathrm{~m} \cdot \mathrm{s}^{-1}$. La velocidad presentó un incremento por la reducción de la sección transversal entre las lagunas y después una disminución por el incremento del área transversal en cada laguna. A partir de la entrada a la laguna Grande de Mandinga, kilómetro 13, la velocidad disminuyó a casi cero (Fig. 3f, h).

Si bien, con el incremento del flujo entre el 18 y 24 de septiembre, hubo una sobreelevación de $10 \mathrm{~cm}$ en la laguna Grande de Mandinga, la variación de la velocidad fue mínima, aunque en la zona de escolleras (punto O1, Fig. 1) las velocidades alcanzaron un valor de $0.8 \mathrm{~m} \cdot \mathrm{s}^{-1}$ (Fig. 4a-d). El efecto dominante entre la descarga del río y la descarga del mar al estuario se estableció mediante la relación Qmar/Qrío, considerando secciones transversales para evaluar los diferentes flujos. La relación Qmar/Qrío indicó que en septiembre hubo un dominio del flujo del río y en abril un control del sistema por la marea (Fig. 4e, f).

Un análisis bidimensional de las velocidades mostró que, para la condición de estiaje, las velocidades en la superficie fueron de $0.1 \mathrm{~m} \cdot \mathrm{s}^{-1}$ como máximo y en dirección del mar, mientras que en el fondo el sistema presentó velocidades de $0.05 \mathrm{~m} \cdot \mathrm{s}^{-1}$, pero en dirección de entrada al sistema. Este comportamiento fue constante en todas las fases de la marea. Las magnitudes más grandes de la velocidad se presentaron entre la entrada a la laguna y la descarga al mar y disminuyeron hacia la entrada al estuario, así como aguas arriba del río (Fig. 5a-d). Para las condiciones de lluvias el sistema mostró un comportamiento uniforme en la vertical, con descarga del flujo constante hacia el mar, aún en condiciones de pleamar y con una dirección del flujo hacia el interior del estuario. La descarga del río Jamapa impidió la entrada de la marea, por lo que la circulación dentro del sistema lagunar es dominada por el flujo del río (Fig. 5e-h).

La salinidad en la descarga del río al mar, en el punto O1 en condiciones de estiaje, fue de entre 23 en la superficie y 33 en el fondo (Fig. 6a). En condiciones de lluvias, los valores de salinidad fueron de 4 en la superficie y 20 en el fondo; por lo tanto, hubo una menor mezcla debido al incremento de flujo del río Jamapa (Fig. 6b). A medida que el flujo del río se incrementó, los valores de salinidad tendieron a cero, condición que se presenta entre el 19 y 21 de septiembre, cuando la descarga del río alcanzó valores mayores que $300 \mathrm{~m}^{3} \cdot \mathrm{s}^{-1}$ (Fig. 6b). 

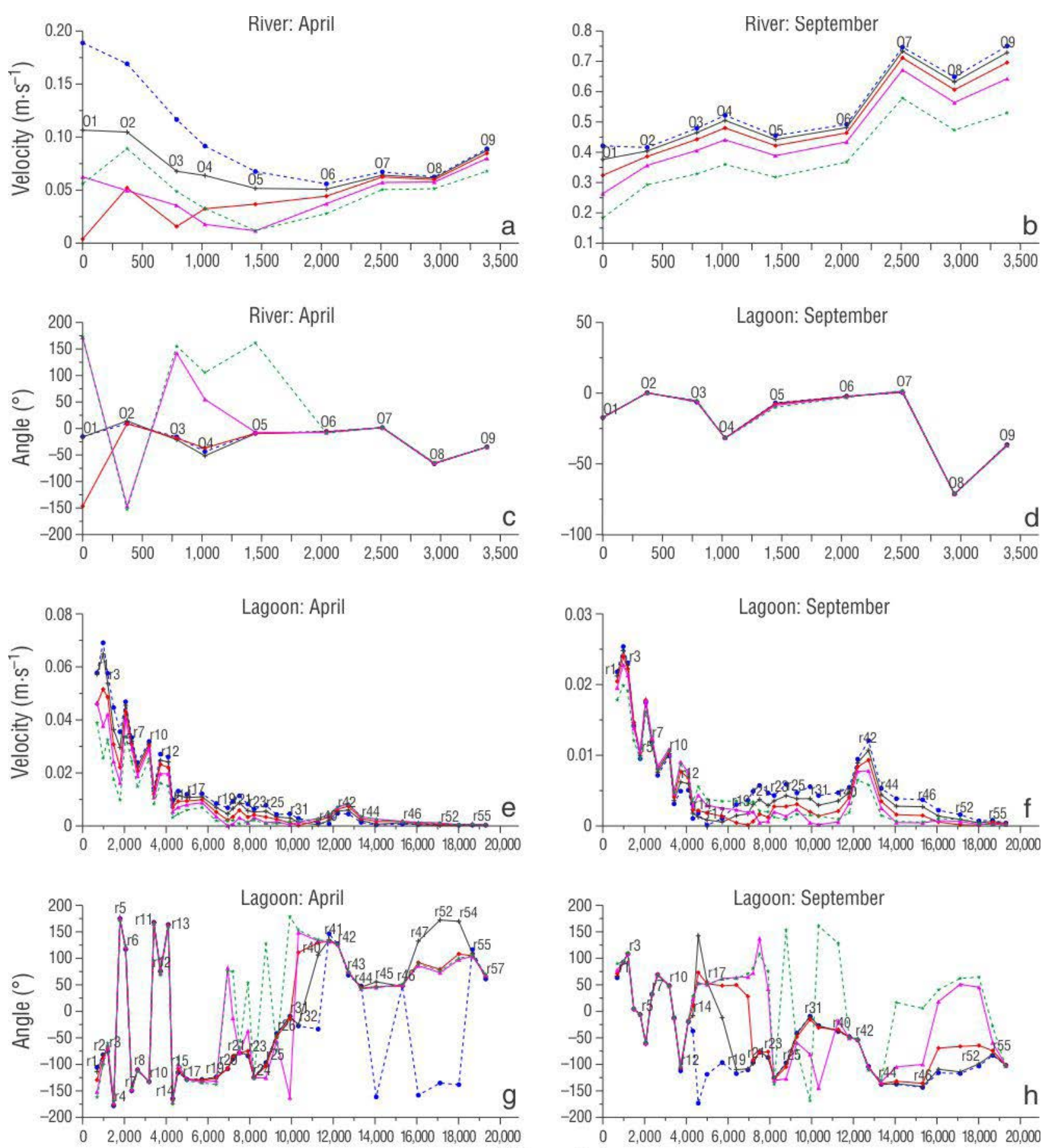

Distance $(\mathrm{m})$

$$
\bullet \bullet-E 1 \quad \longleftrightarrow \text { E2 } \leftrightarrow \text { E3 } \leftrightarrow \text { E4 } \nrightarrow \text { E5 }
$$

Figure 3. Model output: Velocity (a, b, e, f) and velocity direction (c, d, g, h). Water surface (E1), bottom layer (E5); positive angle indicates entrance to the system.

Figura 3. Salida del modelo: (a, b, e, f) velocidad y (c, d, g, h) dirección de velocidad. E1 indica el estrato en superficie del agua y E5 el estrato en el fondo; ángulo positivo indica entrada al sistema. 

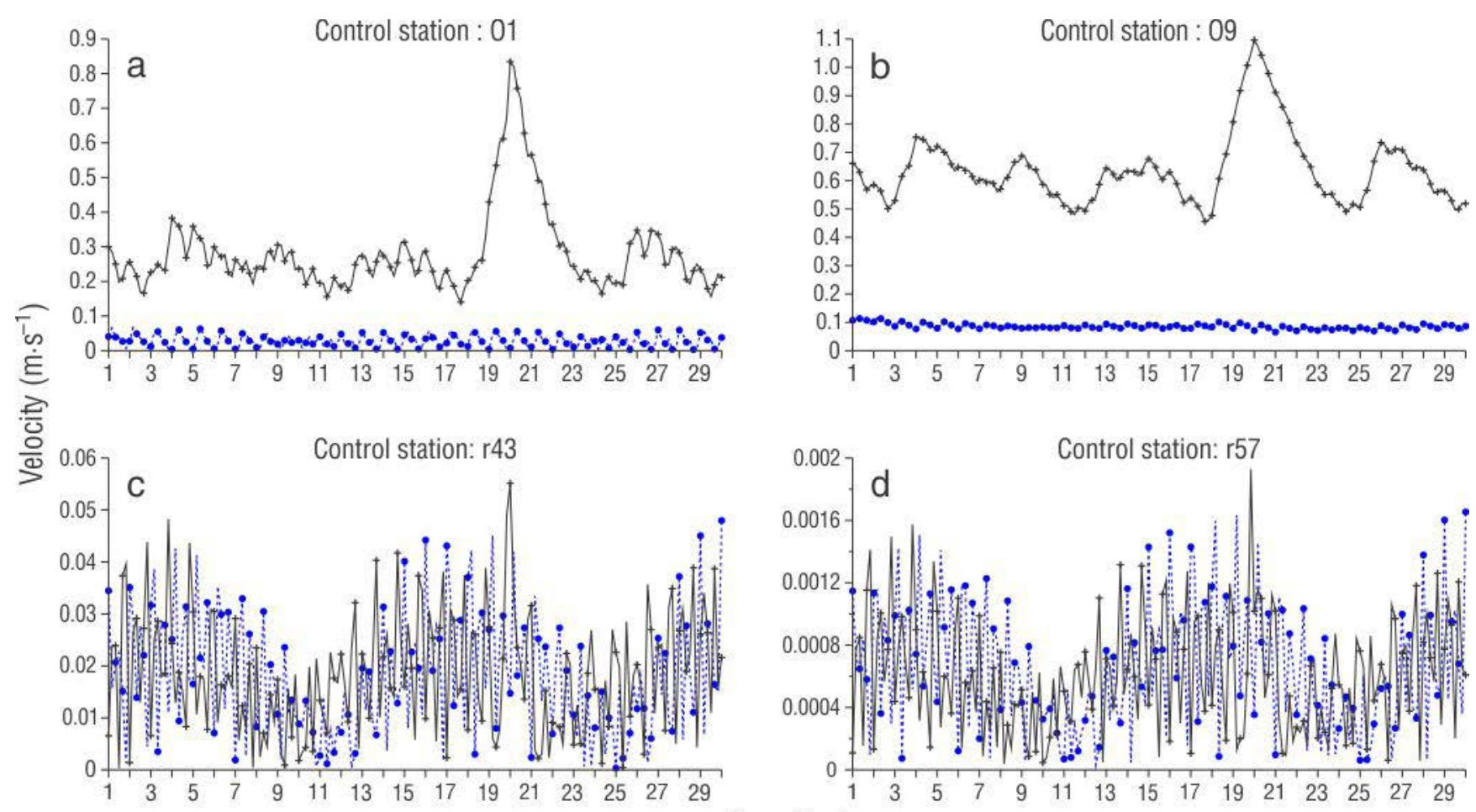

Time (day)
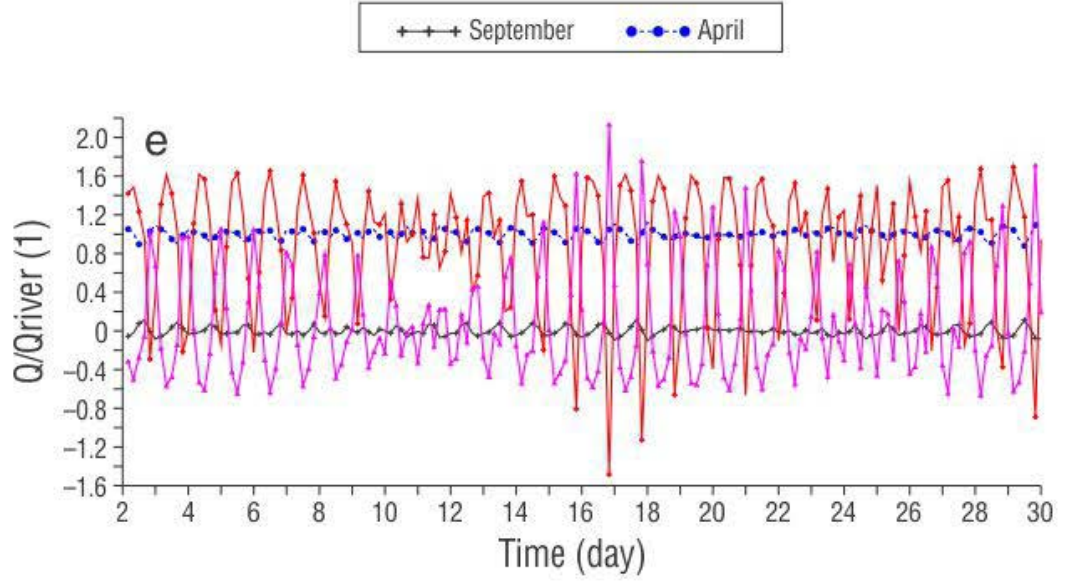

$\bullet$ Qsea/Qriver September $\rightleftarrows$ Qlagoon/Qriver September $\because$ Qsea/Qriver April $\quad \ldots$ Qlagoon/Qriver April

Figure 4. Average flow velocity at control stations: (a) O1, (b) O9, (c) r43, (d) r57. (e) Water-discharge relation.

Figura 4. Velocidad promedio del flujo en las estaciones de control: (a) O1, (b) O9, (c) r43, (d) r57. (e) Relación de descarga de flujo.

At station $\mathrm{O} 1$, the seaward river discharge showed salinity values of 23 at the surface and 33 at the bottom during dry conditions (Fig. 6a). Whereas, salinity values were 4 at the surface and 20 at the bottom during rainy conditions; mixing during this condition decreased because the Jamapa River flux increased (Fig. 6b). Salinity values tended to zero when river flux increased; this was observed between 19 and 21 September, when river discharge reached values $>300 \mathrm{~m}^{3} \cdot \mathrm{s}^{-1}$ (Fig. 6b).
En el interior de la laguna Grande de Mandinga, en condiciones de estiaje o lluvias y bajo cualquier fase de la marea, la salinidad en la vertical fue uniforme, como resultado de los intercambios de flujo, de temperatura y de concentración salina en las secciones más estrechas (Fig. 6c). La reducción en el flujo proveniente de la marea por el incremento del flujo del río fue reflejada en la disminución de la salinidad en la laguna (Fig. 6d). La tendencia a disminuir de la salinidad en la laguna 
Inside the Mandinga Grande Lagoon, during the dry and rainy seasons and with all phases of the tide, salinity values were uniform at all depths levels as a result of intense mixing and homogenization of the system caused by flux exchange in the narrowest sections, temperature, and flux direction changes (Fig. 6c). Salinity in the lagoon decreased because the river flux increased and caused the flux from the tide to decrease (Fig. 6d). Salinity tends to decrease in the Mandinga Grande Lagoon during dry and rainy periods because any
Grande de Mandinga, ya sea en los periodos de lluvia o de estiaje, se debió a una aportación de volumen del flujo del río que, por muy poca que fuere en el sistema, diluyó la concentración de sal. En un análisis bidimensional de la salinidad en el río Jamapa en condiciones de estiaje, los valores tendieron a cero a $2 \mathrm{~km}$ aguas arriba del río, mientras que en condiciones de lluvias los valores variaron de cero a $0.5 \mathrm{~km}$ aguas arriba a partir de la frontera con el mar (Fig. 6e, f). La condición de la salinidad en la laguna

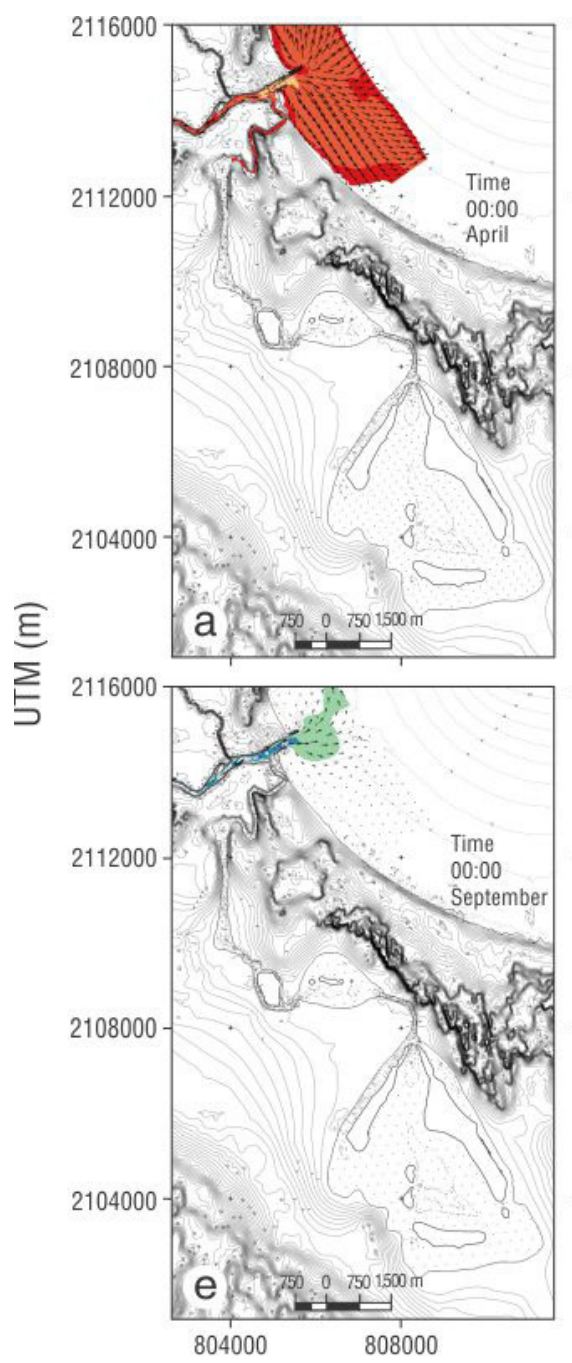

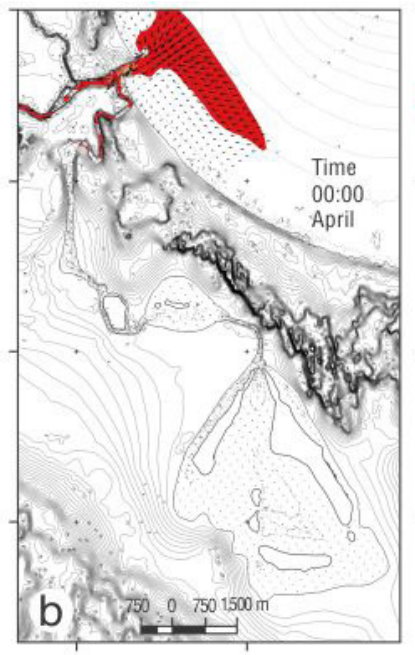
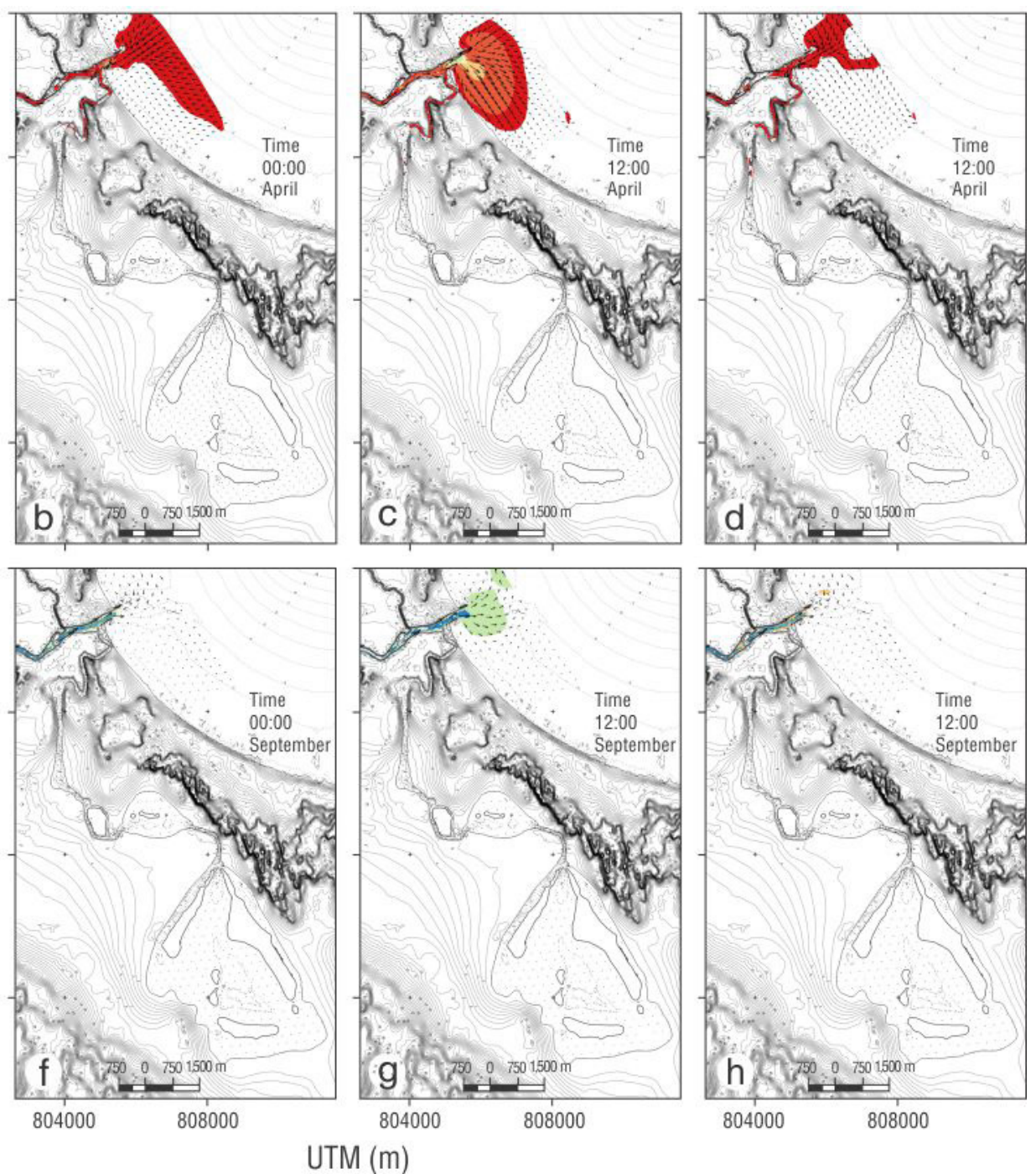

$\operatorname{UTM}(\mathrm{m})$

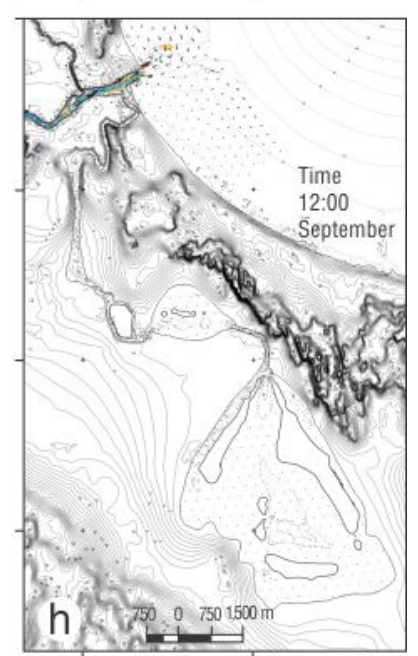

804000

808000

Velocity $\left(\mathrm{m} \cdot \mathrm{s}^{-1}\right)$

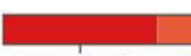 \\ $0.010-0.047 \quad 0.047-0.095 \quad 0.095-0.095 \quad 0.095-0.142 \quad 0.142-0.142 \quad 0.142-0.171 \quad 0.171-0.190 \quad 0.190-0.237 \quad 0.237-0.303 \quad 0.303-0.474$}

Figure 5. Velocity magnitude and direction. E1 indicates the free surface layer and E5 the bottom layer. Dry season: (a) E1 during high water, (b) E5 during high water, (c) E1 during low water, (d) E5 during low water. Rainy season: (e) E1 during high water, (f) E5 during high water, (g) E1 during low water, (h) E5 during low water.

Figura 5. Magnitud y dirección de velocidad. E1 indica el estrato en superficie del agua y E5 el estrato en el fondo. Temporada de estiaje: (a) E1 en marea alta, (b) E5 en marea alta, (c) E1 en marea baja, (d) E5 en marea baja. Temporada de lluvias: (e) E1 en marea alta, (f) E5 en marea alta, (g) E1 en marea baja, (h) E5 en marea baja. 
González-Vazquez et al.: Diagnosis of water circulation in an estuary in Veracruz
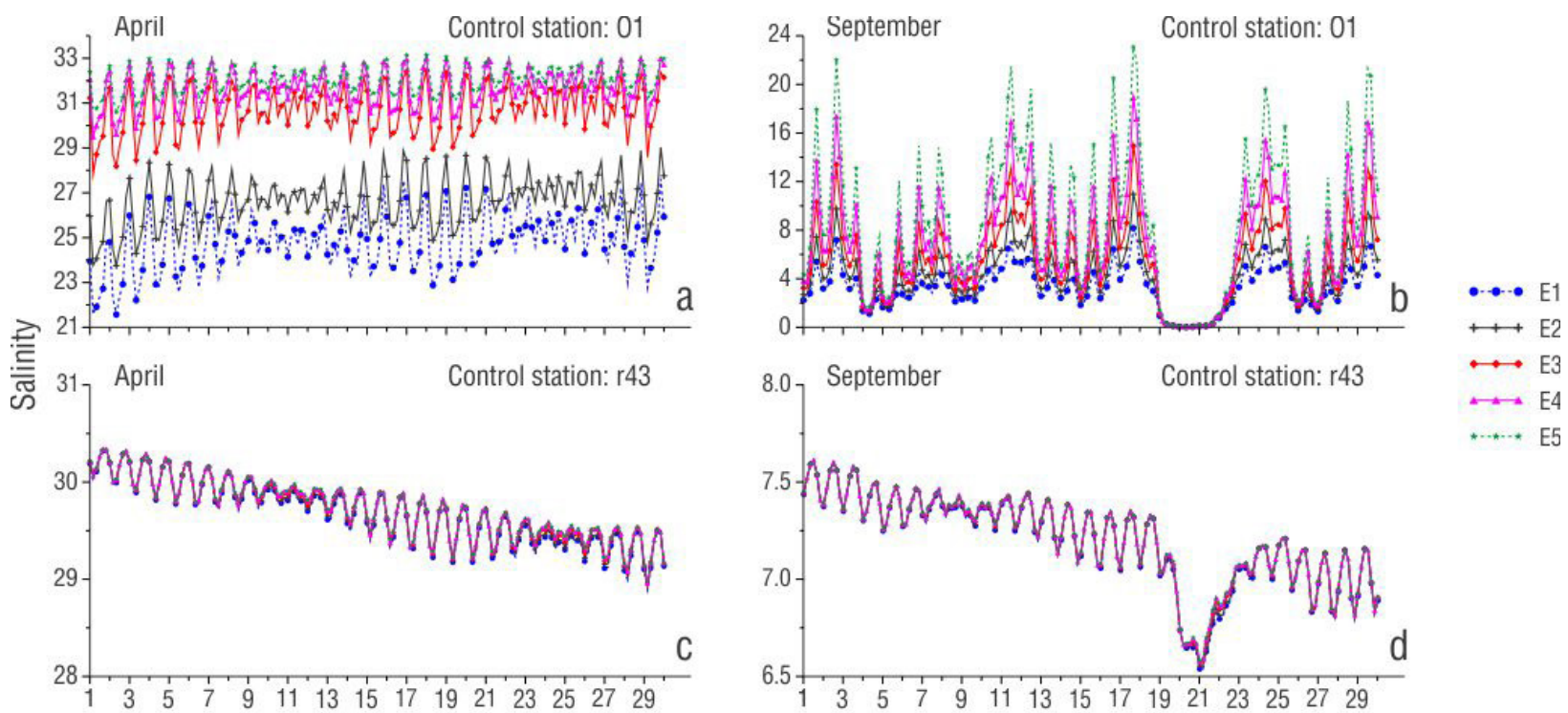

Time (day)

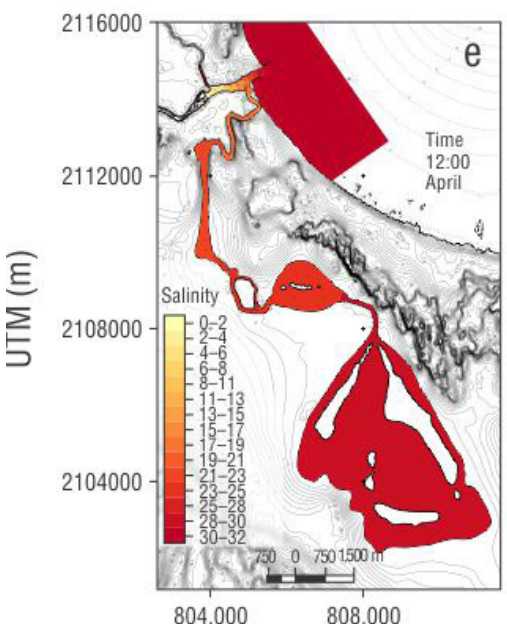

$804,000 \quad 808,000$

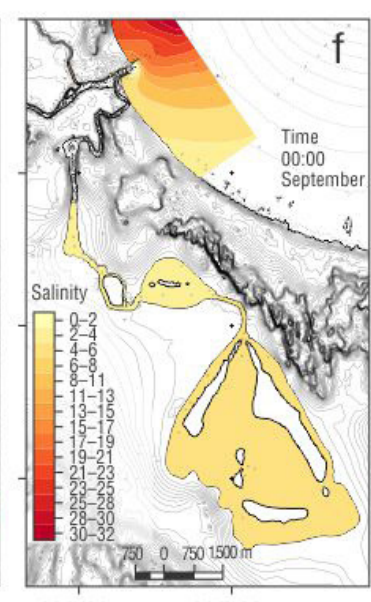

$804000 \quad 808000$

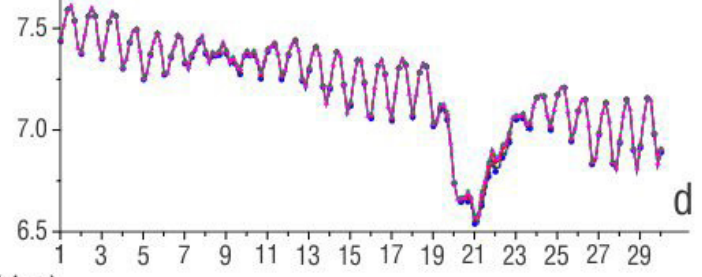

d

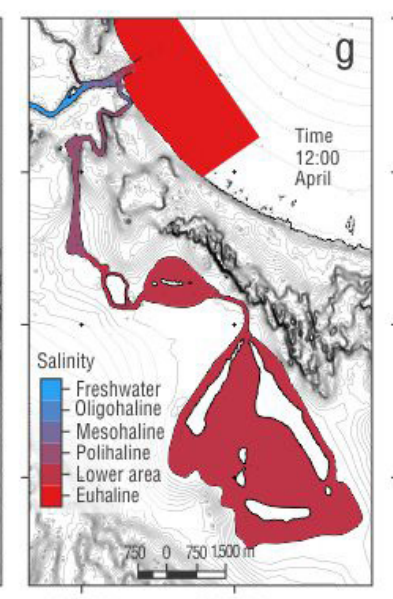

$804000 \quad 808000$

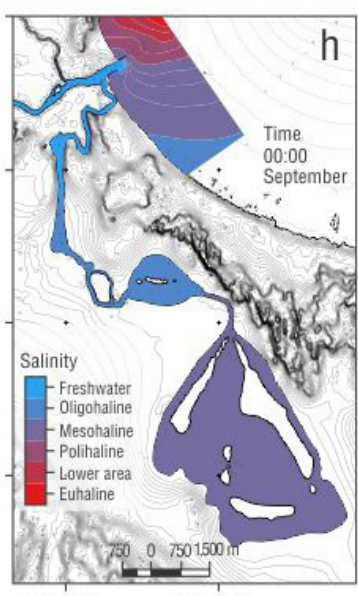

$804000 \quad 808000$

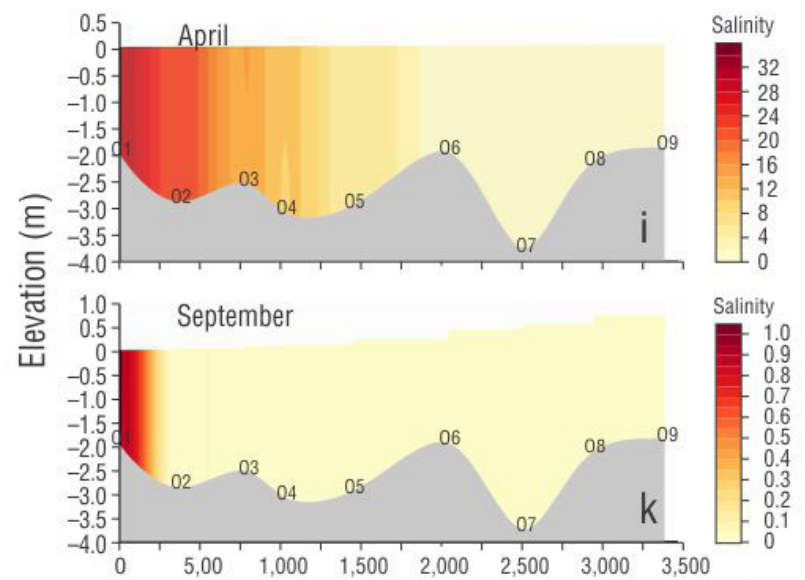

Distance $(\mathrm{m})$
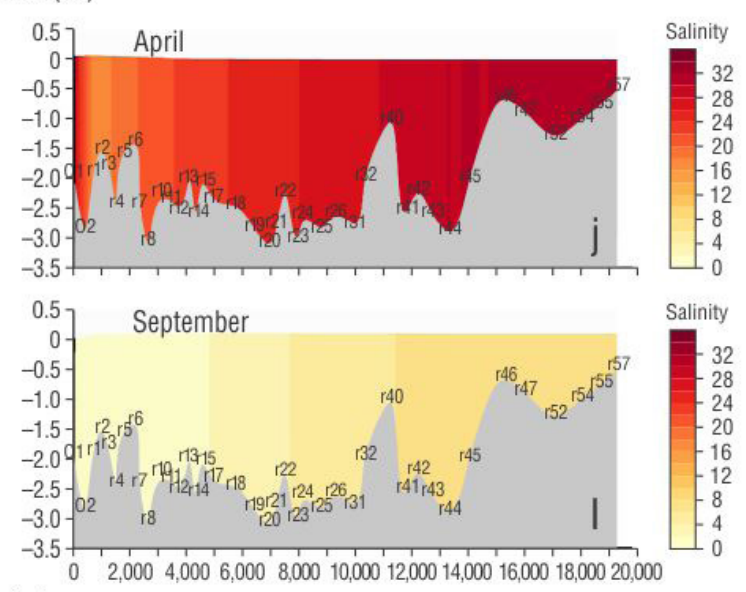

Figure 6. Salinity by layer (E1-E5) at O1 during (a) dry season and (b) rainy season and at r43 during (c) dry season and (d) rainy season. 2D salinity at E5 during (e) dry season and (f) rainy season. Classification Venice System Scheme for (g) dry season; (h) rainy season; (i) profile of salinity in the river, dry season;(j) profile of salinity in the lagoon, dry season; (k) profile of salinity in the river, rainy season; (I) profile of salinity in the lagoon, rainy season.

Figura 6. Salinidad en cada estrato (E1-E5) en O1 durante la temporada de (a) estiaje y (b) lluvias y en r43 durante la temporada de (c) estiaje y (d) lluvias. Salinidad 2D en E5 durante (e) el estiaje y (f) las lluvias. Clasificación VSS para (g) estiaje; (h) lluvias; (i) perfil de salinidad en el río, estiaje; (j) perfil de salinidad en la laguna, estiaje; (k) perfil de salinidad en el río, lluvias; y (l) perfil de salinidad en la laguna, lluvias. 
flux from the river dilutes salinity. A bidimensional analysis of salinity in the Jamapa River showed that in dry conditions salinity tended to zero $2 \mathrm{~km}$ upstream, whereas in rainy conditions values were zero $0.5 \mathrm{~km}$ upstream from the boundary with the sea (Fig. 6e, f). Salinity increased the most during the dry season and expanded into the inner part of the Mandiga Grande Lagoon with salinity values of 30 . During the dry season, the flux entered predominantly from the sea and caused higher salinity values (Fig. 6e). During the rainy season, salinity decreased to 8 in the Mandinga Grande Lagoon (Fig. 6f).

Longitudinal sections of salinity during the dry and rainy seasons showed a constant value at all depths; only at the breakwaters, where the river interacts the most with the sea, was there a significant variation (station O1). Temperature variations tend to form density and convection gradients forced by water exchange; this causes water to mix in the system and density to vary in shallow zones. Temperature variations in shallow zones together with the near-zero velocity in the lagoons caused density variations (Fig. 6i-l).

The system was classified using the Venice System Scheme (The Venice system... 1958) to determine the condition variability of the circulation and stratification associated with the behavior of the lagoon during dry and rainy seasons. During the dry season, the system reached euhaline values and was apt for marine fish; during the rainy season, the system showed mesohaline values, which made it a markedly low-salinity system apt for freshwater organisms.

\section{Discussion}

Velocity conditions tend to be near zero soon after entering the lagoon system, which indicates that the system has low mobility. An analysis of the momentum equation (Jian and $\mathrm{Li}$ 2012) is done to determine circulation: presentó un mayor incremento en condiciones de estiaje, con valores de 30 en el interior de la laguna Grande de Mandinga. En condiciones estiaje, el flujo que entró, en su mayoría, provino del mar y, debido a la poca circulación, la salinidad aumentó (Fig. 6e). En condiciones de lluvias, la salina se redujo hasta 8 en la laguna Grande de Mandinga (Fig. 6f).

Las secciones longitudinales de salinidad en las condiciones de estiaje y de lluvias, mostraron un valor constante en la vertical. Se observó una variación significativa solo en la zona de escolleras, que es la zona de mayor interacción entre el río y el mar (punto O1). La variación de la temperatura tendió a formar un gradiente de densidad y a generar convección, forzada por el intercambio de agua, originando las mezclas de agua en el sistema, así como la variación de densidad en las zonas someras. La variación de la temperatura en las zonas someras, aunado a la casi nula velocidad en las lagunas, provocará una variación en la densidad (Fig. 6i-l).

Para establecer la variabilidad de las condiciones en la circulación y la estratificación con el comportamiento de la laguna en condiciones de estiaje y de lluvias, se clasificó el sistema usando el criterio Venice System Scheme (The Venice system... 1958). En condiciones de estiaje el sistema alcanzó valores euhalinos, algo propio para el ingreso de peces marinos, mientras que en condiciones de lluvias alcanzó valores mesohalinos, lo cual genera un sistema de baja salinidad y, consecuentemente, favorece la presencia de organismos de agua dulce.

\section{Discusión}

Las condiciones de velocidad tienden a ser próximas a cero poco después de la entrada al sistema lagunar, lo cual indica que el sistema tiene poca movilidad. Para analizar la circulación se realiza un análisis de la ecuación de momento (Jian y Li 2012):

$$
\begin{gathered}
\frac{\partial u}{\partial t}=-g \frac{\partial \eta}{\partial x}-\frac{g}{\rho} \int_{z}^{\eta} \frac{\partial \rho^{\prime}}{\partial x} d z^{\prime}+\frac{1}{\rho} \frac{\partial \tau_{x z}}{\partial z}+f v-\left\{u \frac{\partial u}{\partial x}+v \frac{\partial u}{\partial y}+w \frac{\partial u}{\partial z}\right\} \\
0=\int_{-h}^{\eta}-g \frac{\partial \eta}{\partial x} d z+\int_{-h} \eta_{-h}\left\{-\frac{g}{\rho} \int_{z}^{\eta} \frac{\partial \rho^{\prime}}{\partial x} d z^{\prime}\right\} d z+\frac{\tau_{s}}{\rho}-\frac{\tau_{b}}{\rho}+\int_{-h}^{\eta} f v d z-\int_{-h}^{\eta}\left\{u \frac{\partial u}{\partial x}+v \frac{\partial u}{\partial y}+w \frac{\partial u}{\partial z}\right\} d z
\end{gathered}
$$

where $u, v$, and $w$ are the velocity components, $\eta$ is the free surface elevation, $\rho$ ' is density, $\tau_{x z}$ is the Reynolds shear stress, $f$ is the Coriolis parameter, $\tau_{\mathrm{b}}$ is shear stress at the bottom (friction), and $\tau_{\mathrm{s}}$ is the shear stress at the free surface (wind stress); the terms from left to right represent the following forcings: barotropic pressure gradient, baroclinic pressure gradient, shear stress at the surface, shear stress at the bottom, Coriolis effect, and donde $U, v$ y $w$ son los componentes de velocidad, $\eta$ es la elevación de la superficie libre, $\rho$ ' es la densidad, $\tau_{x z}$ es el cortante de Reynolds, $f$ es el parámetro de coriolis, $\tau_{\mathrm{b}}$ es el esfuerzo cortante en el fondo (fricción) y $\tau_{\mathrm{s}}$ es el esfuerzo cortante en la superficie libre (esfuerzo por viento); cada término, de izquierda a derecha, representa los siguientes forzantes: gradiente de presión barotrópica, gradiente de presión baroclínica, esfuerzo cortante en la superficie, esfuerzo cortante 
advection. For the present study, the forcing agents in the system are the river and tide fluxes; the wind and the Coriolis effect were not considered. The analysis was done at $1 \mathrm{~m}$ depth, which is the depth of the Mandinga Grande Lagoon; hence, the momentum equation can be re-written as follows: en el fondo, efecto de Coriolis y advección. En este estudio los forzantes en el sistema son el flujo del río y el flujo de la marea, sin considerar el viento y el efecto de Coriolis, y el análisis abarcó $1 \mathrm{~m}$ de profundidad, que corresponde a la profundidad de la laguna Grande de Mandinga; por lo tanto, la ecuación de momento puede reescribirse como sigue:

$$
0=\int_{-h}^{\eta}-g \frac{\partial \eta}{\partial x} d z+\int_{-h}^{\eta}\left\{-\frac{g}{\rho} \int_{z}^{\eta} \frac{\partial \rho^{\prime}}{\partial x} d z^{\prime}\right\} d z-\frac{\tau_{b}}{\rho}-\int_{-h}^{\eta}\left\{u \frac{\partial u}{\partial x}+v \frac{\partial u}{\partial y}+w \frac{\partial u}{\partial z}\right\} d z
$$

Two analyses of the momentum equation (eq. 3) were done, one for the dry season and one for the rainy season for the section of the lagoon system. For the dry season, salinity values were near 30 and $0.02 \mathrm{~m}$ above MLLW at Mandinga Grande Lagoon. From the momentum equation, it was determined that fluxes moved due to a baroclinic condition caused by a horizontal density gradient between the breakwaters (station O1) and the Mandinga Grande Lagoon (Fig. 7a-d). During the rainy season, with salinity values of nearly 5 and elevation of the breakwater zone at $1.02 \mathrm{~m}$, variation of horizontal density was limited by the discharge of the Jamapa River, which reduced baroclinic pressure; however, the increase in river flux increased horizontal variation in the free surface and thus caused a greater inclination, which produced a greater barotropic pressure condition (Fig. 8).

The circulation in the lagoon system was affected directly by variations in the flux of the Jamapa River during dry and rainy seasons, from 14 to $350 \mathrm{~m}^{3} \cdot \mathrm{s}^{-1}$, respectively. The free surface allowed us to determine the response velocity of the lagoon to changes in the Jamapa River flux: the maximum flux was observed in station O9 on 20 April at 00:00 h, whereas the highest elevation value in the Mandinga Grande Lagoon was observed on 21 April at approximately 12:00 h; therefore, the response velocity to the behavior of the river in the Mandinga Grande Lagoon is almost $36 \mathrm{~h}$. The increase of the river flux also translated into a lack of inflow into the system of water masses from the sea; hence, the Jamapa River flux dominated the lagoons. Changes of velocity during the dry season, as a response to the flux reduction, caused a permanent tide inflow; this carried water with greater density and produced vertical stratification in the breakwaters; and thus, vertical variations in the direction of velocities. When the flux increased stratigraphy disappeared and a constant profile with a seaward direction formed.

This study showed that circulation in the system depended on the season, caused by changes in the flux of the Jamapa River. The rainy season reduced salt intrusions in the lagoon system and caused a decrease of baroclinic pressure; in addition, a horizontal gradient caused variations in barotropic pressure due to variations in the free surface. Thus, flux reduction allowed the tide
Se consideran 2 análisis de la ecuación de momento (ec. 3), en función de la temporada de estiaje y de lluvias para la sección del sistema lagunar. Para la temporada de estiaje, las condiciones de salinidad serán con valores próximos a 30 y de $0.02 \mathrm{~m}$ arriba del nivel de bajamar media inferior en la laguna Grande de Mandinga. De la ecuación de momento, se establece que el movimiento del flujo se debe a una condición baroclínica, ya que existe un gradiente de densidad horizontal entre la zona de escolleras (punto O1) y la laguna Grande Mandinga (Fig. 7a-d). En condiciones de lluvias, con valores próximos a 5 de salinidad y de $1.02 \mathrm{~m}$ de altura en la zona de escolleras, la variación horizontal de la densidad está limitada por la descarga del flujo del río Jamapa, por lo que la variación por presión baroclínica decrece, pero el incremento del flujo en el río aumenta la variación horizontal en la superficie libre; por lo tanto, se produce una inclinación mayor y se genera una mayor condición de presión barotrópica (Fig. 8).

La variación de los flujos en el río Jamapa, para condiciones de estiaje y de lluvias de $14 \mathrm{y} 350 \mathrm{~m}^{3} \cdot \mathrm{s}^{-1}$, respectivamente, afecta directamente la circulación del sistema lagunar. La variación de la superficie libre permite determinar la velocidad de respuesta de la laguna a los cambios del flujo del río Jamapa. Mientras que el nivel máximo se presentó en el punto O9 el día 20 de abril a las 00:00, el valor de mayor elevación en la laguna Grande de Mandinga se presentó el 21 de abril a las 12:00, aproximadamente, por lo que la respuesta de la laguna Grande de Mandinga al comportamiento del río es de casi 36 h. El incremento del flujo en el río también tendrá como resultado que el agua proveniente del mar no ingrese al sistema, de tal forma que el flujo del río Jamapa domina la circulación en las lagunas. El cambio de la velocidad en condiciones de estiaje, como respuesta a la reducción del flujo del río, permite un ingreso permanente de la marea al sistema, con agua de mayor salinidad y densidad que genera una estratificación en la vertical en la zona próxima al mar y, por lo tanto, una variación de direcciones en las velocidades sobre la vertical. $\mathrm{Al}$ aumentar el flujo del río, desaparece la estratificación y se forma un perfil verticalmente homogéneo con velocidades en dirección al mar.

El estudio refleja una circulación en función de la temporada del año en el sistema, como producto del cambio 

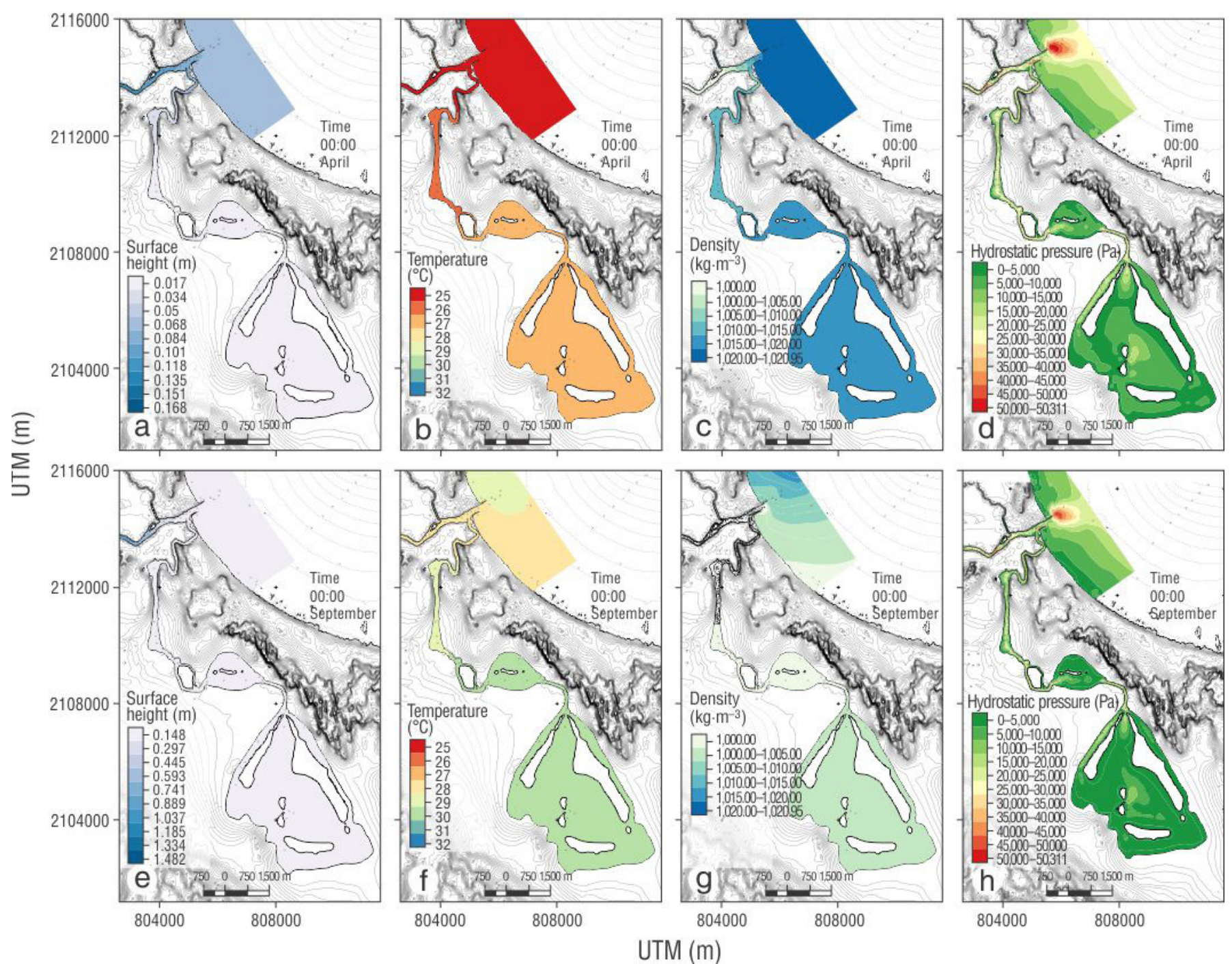

Figure 7. (a) Surface height, (b) temperature, (c) density, and (d) pressure during the dry season. (e) Surface height, (f) temperature, (g) density, and (h) pressure during the rainy season.

Figura 7. (a) Nivel de superficie, (b) temperatura, (c) densidad y (d) presión durante la temporada de estiaje. (e) Nivel de superficie, (f) temperatura, (g) densidad y (h) presión durante la temporada de lluvias.

to enter the lagoon system, which produced a horizontal density gradient. In addition, there was a lack of inflow from the river, and thus a minimal variation of the free surface and lower values of barotropic pressure. When the tide dominated the system during the dry season, the horizontal density gradient resulted in a baroclinic variation. Hence, we determined that for the dry season baroclinic conditions dominated the system and for the rainy season, barotropic conditions dominated the system. The system presents a natural circulation condition produced by the Jamapa River flow and tide conditions.

English translation by Claudia Michel-Villalobos. de flujo en el río Jamapa. Durante la temporada de lluvias se reduce la intrusión de sal al sistema lagunar, por lo que la presión baroclínica disminuye y, debido a la variación de la superficie libre, existe un gradiente horizontal que genera una variación de presión barotrópica. Durante la temporada de estiaje, la reducción del flujo del río permitirá el ingreso de la marea al sistema lagunar, generando un gradiente horizontal de densidad; por lo tanto, la variación de la superficie libre será poca y la presión barotrópica será menor. Cuando el sistema es regido por la marea, esto es en condiciones de estiaje, el gradiente horizontal de densidad tendrá como resultado una variación baroclínica en el sistema. Se establece, entonces, que el sistema 
González-Vazquez et al.: Diagnosis of water circulation in an estuary in Veracruz
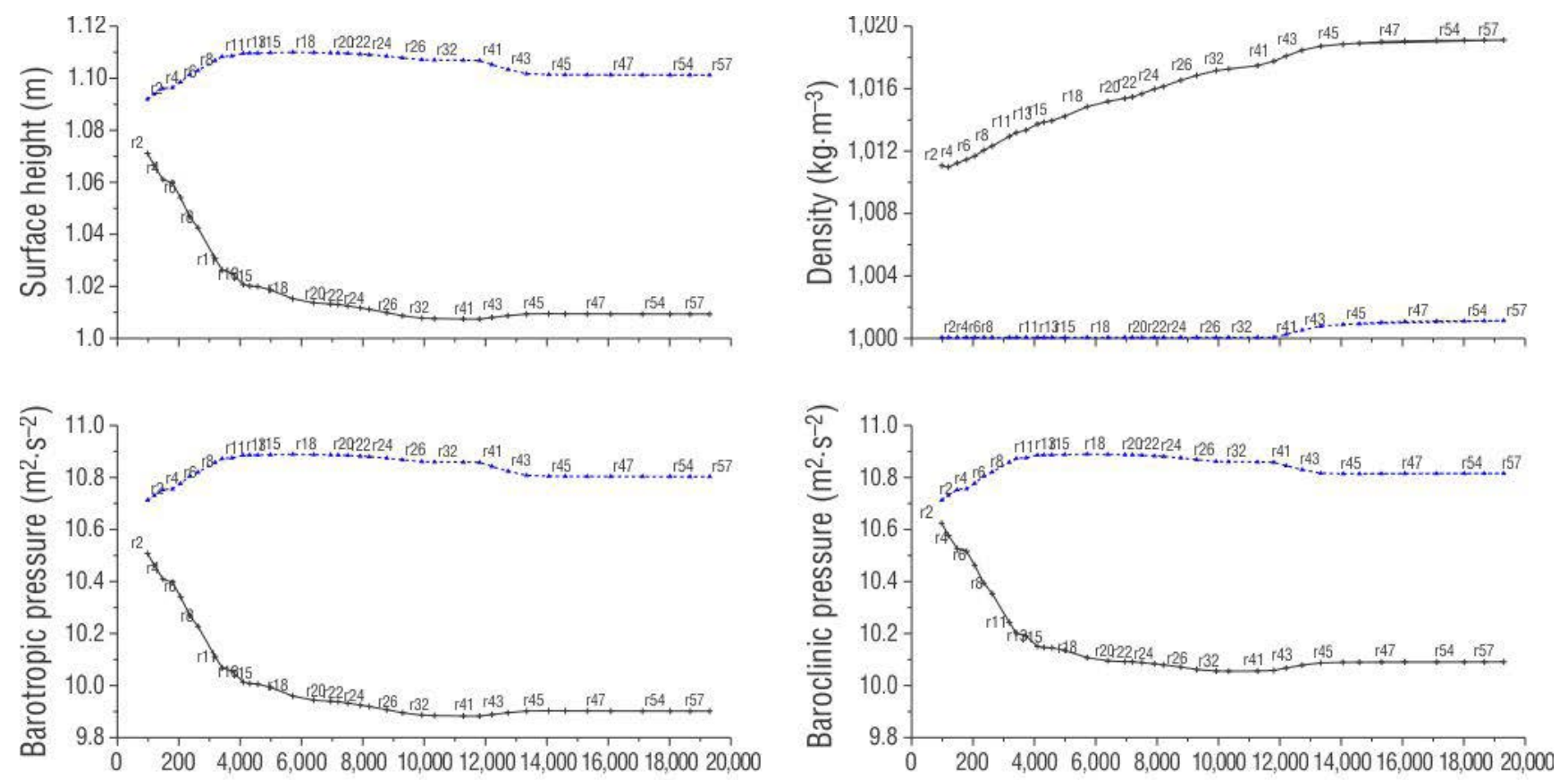

Distance (m)

$$
+ \text { April } \quad \ldots \ldots \text {.... September }
$$

Figure 8. (a) Free surface height, (b) density, (c) barotropic pressure, and (d) baroclinic pressure.

Figura 8. (a) Nivel de superficie libre, (b) densidad, (c) presión barotrópica y (d) presión baroclínica.

\section{REFERENCES}

Barrios-Piña H, Ramírez-León H, Cuevas-Otero A, TorresBejarano F, Ponce-Palafox JT. 2016. Numerical modeling of hydrodynamics in the Agua Brava Lagoon, located in Nayarit, Mexico. In: Klapp J, Sigalotti L, Medina A, López A, RuizChavarría G (eds), Recent Advances in Fluid Dynamics with Environmental Applications. Environmenal Science and Engineering. Springer, Cham, p. 167-180. https://doi.org/10.1007/978-3-319-27965-7_13

Carlin JA, Lee GH, Dellapenna TM, Laverty P. 2016. Sediment resuspension by wind, waves, and currents during meteorological frontal passages in a micro-tidal lagoon. Estuar. Coast. Shelf Sci. 172: 24-33. https://doi.org/10.1016/j.ecss.2016.01.029

Chow VT. 1959. Open-Channel Hydraulics. Vol. 1. New York: McGraw-Hill.

[CONAGUA] Comisión Nacional del Agua (MX). 2012. Banco Nacional de Datos de Aguas Superficiales, BANDAS. [accessed 2018 July]. http://www.conagua.gob.mx/CONAGUA07/ Contenido/Documentos/Portada\%20BANDAS.htm

Farreras S. 2006. Hidrodinámica de lagunas Costeras. Mexico: Centro de Investigación Científica y de Educación Superior de Ensenada, $184 \mathrm{pp}$.

Gill AE, Rasmusson EM. 1983. The 1982-83 climate anomaly in the equatorial Pacific. Nature 306(5940): 229-234 https://doi.org/10.1038/306229a0

Hydraulics Deltares. 2006. User Manual of Delft3D-FLOWSimulation of Multi-dimensional Hydrodynamic Flows and Transport Phenomena, Including Sediments. The Netherlands: Delft, 614 pp. estará regido por condiciones de presión baroclínica en condiciones de estiaje y condiciones de presión barotrópica en condiciones de lluvia. El sistema presenta una condición de circulación natural como función directa del flujo del río Jamapa y las condiciones de marea.

González-Vázquez JA, Hernández-Vivar E, Jacobo-Villa MA 2018. Análisis de circulación en estuarios. In: Lecertúa E, Lopardo MC, Menéndez A, Spalletti P (eds.), XXVIII Congreso Latinoamericano de Hidráulica: Trabajos Completos; 2018 September 18-21, Buenos Aires, Argentina. Argentina, 2281-2293.

Jia P, Li M. 2012. Circulation dynamics and salt balance in a lagoonal estuary. Journal of Geophysical Research: Oceans 117(C1). https://doi.org/10.1029/2011JC007124

Lesser GR, Roelvink JA, Van Kester JATM, Stelling GS. 2004. Development and validation of a three-dimensional morphological model. Coast. Eng. 51(8-9): 883-915. https://doi.org/10.1016/j.coastaleng.2004.07.014

Mahanty MM, Mohanty PK, Pattnaik AK, Panda US, Pradhan S, Samal RN. 2016. Hydrodynamics, temperature/salinity variability and residence time in the Chilika lagoon during dry and wet period: Measurement and modeling. Cont. Shelf Res. 125: 28-43. https://doi.org/10.1016/j.csr.2016.06.017 
Paerl H, Pinckney JL, Fear JM, Peierls BL. 1998. Ecosystem responses to internal and watershed organic matter loading: consequences for hypoxia in the eutrophying Neuse River Estuary, North Carolina, USA. Mar. Ecol. Prog. Ser. 166: $17-25$. https://doi.org/10.3354/meps166017

Panda US, Mohanty PK, Samal RN. 2013. Impact of tidal inlet and its geomorphological changes on lagoon environment: A numerical model study. Estuar. Coast. Shelf Sci. 116: 29-40. https://doi.org/10.1016/j.ecss.2012.06.011

Pritchard DW. 1967. What is an estuary: a physical viewpoint. AAAS 83: 3-5. http://hdl.handle.net/1969.3/24383

Riveron-Enzastiga ML, Carbajal N, Salas-Monreal D. 2016. Tropical coral reef system hydrodynamics in the western Gulf of Mexico. Sci. Mar. 80(2): 237-246. https://doi.org/10.3989/scimar.04259.15B

Roelvink JA, Van Banning GKFM. 1995. Design and development of DELFT3D and application to coastal morphodynamics. Oceanograph. Lit. Rev. 11(42): 925.

Salas-Monreal D, Anis A, Salas-de-Leon DA. 2018. Galveston Bay dynamics under different wind conditions. Oceanologia 60(2): 232-243. https://doi.org/10.1016/j.oceano.2017.10.005

Salas-Monreal D, Valle-Levinson A, Athie G. 2019. Flow modifications over a tropical coral reef system. Estuar. Coast. Shelf Sci. 217: 271-280.

https://doi.org/10.1016/j.ecss.2018.11.029
[SEMAR] Secretaría de Marina (MX). 2010. Tablas numéricas de predicción de mareas 2010. Mexico: Secretaría de MarinaArmada de México.

The Venice system for the classification of marine waters according to salinity. 1958. Limnol. Oceanogr. 3: 346-347. https://doi.org/10.4319/lo.1958.3.3.0346

Vargas CIC, Vaz N, Dias JM. 2017. An evaluation of climate change effects in estuarine salinity patterns: Application to Ria de Aveiro shallow water system. Estuar. Coast. Shelf Sci. 189: 33-45. https://doi.org/10.1016/j.ecss.2017.03.001

Xu F, Coco G, Zhou Z, Tao J, Zhang C. 2017. A numerical study of equilibrium states in tidal network morphodynamics. Ocean Dyn. 67(12): 1593-1607. https://doi.org/10.1007/s10236-017-1101-0

Werner FE, Blanton BO, Quinlan JA, Luettich RA. 1999. Physical oceanography of the North Carolina continental shelf during the fall and winter seasons: implications for the transport of larval menhaden. Fish. Oceanogr. 8(s2): $7-21$. https://doi.org/10.1046/j.1365-2419.1999.00016.x

Zhu J, Weisberg RH, Zheng L, Qi H. 2015. On the salt balance of Tampa Bay. Cont. Shelf Res. 107: 115-131. https://doi.org/10.1016/j.csr.2015.07.001

Received October 2018, accepted March 2019. 